\title{
Methods of Plant Transformation- A Review
}

\author{
G. Keshavareddy ${ }^{1 *}$, A.R.V. Kumar ${ }^{1}$ and Vemanna S. Ramu ${ }^{2}$ \\ ${ }^{1}$ Department of Entomology, ${ }^{2}$ Department of Crop Physiology, University of Agricultural \\ Sciences, GKVK, Bengaluru-560065, Karnataka, India \\ *Corresponding author
}

\begin{tabular}{|c|c|}
\hline & A B S T R A C T \\
\hline $\begin{array}{l}\text { Transformation, } \\
\text { Transgenic, Gene, } \\
\text { Agrobacterium, } \\
\text { Particle }\end{array}$ & \multirow{3}{*}{$\begin{array}{l}\text { Plant transformation is now a core research tool in plant biology and a practical tool for } \\
\text { transgenic plant development. There are many verified methods for stable introduction of } \\
\text { novel genes into the nuclear genomes of diverse plant species. As a result, gene transfer } \\
\text { and regeneration of transgenic plants are no longer the factors limiting the development } \\
\text { and application of practical transformation systems for many plant species. However, the } \\
\text { desire for higher transformation efficiency has stimulated work on not only improving } \\
\text { various existing methods but also in inventing novel methods. The most published } \\
\text { techniques for gene transfer into plant cells were dismissed as either disproven or } \\
\text { impractical for use in routine production of transgenic plants. In many laboratories, } \\
\text { virtually all the transformation work relies on particle bombardment with DNA coated } \\
\text { microprojectiles or Agrobacterium mediated transformation for gene transfer to produce } \\
\text { transgenic plants from a range of plant species. }\end{array}$} \\
\hline Article Info & \\
\hline $\begin{array}{l}\text { Accepted: } \\
\text { 20 June } 2018 \\
\text { Available Online: } \\
\text { 10 July } 2018\end{array}$ & \\
\hline
\end{tabular}

\section{Introduction}

Plant genetic transformation permits direct introduction of agronomically useful genes into important crops and offers a significant tool in breeding programs by producing novel and genetically diverse plant materials. The directed desirable gene transfer from one organism to another and the subsequent stable integration and expression of a foreign gene in the genome is referred to as 'Genetic Transformation'. The transferred gene is known as 'transgene' and the organisms that are developed after a successful gene transfer are known as 'transgenics' (Babaoglu et al., 2000).
Among the various r-DNA technologies, genetically modified plants expressing $\delta$ endotoxin genes from Bacillus thuringiensis $(B t)$, protease inhibitors and plant lectins have been successfully developed, tested and demonstrated to be highly viable for pest management in different cropping systems during the last decade and a half (Gatehouse, 2008). Insect resistant crops have been one of the major successes of applying plant genetic engineering technology to agriculture. Most of the plant derived genes produce chronic rather than toxic effects and many insect pests are less or not sensitive to most of these factors. Therefore, the genes for $\delta$-endotoxins are expected to provide better solutions. 
Advances in biotechnology have provided several unique opportunities that include access to various plant transformation techniques, novel and effective molecules, ability to change the levels of gene expression, capability to change the expression pattern of genes, and develop transgenics with different insecticidal genes. With the advent of genetic transformation techniques based on recombinant DNA technology, it is now possible to insert foreign genes that confer resistance to insects into the plant genome (Bennett, 1994). To sustain the crop yield potential and to meet the growing demand for food, crop productivity needs to be increased. However, in most crops it is believed that the genetic potential has been fully exploited for yield increase. As a result, any improvement in productivity has to revolve around the reduction of losses due to pests and diseases under optimal nutrition and abiotic factors. Recombinant DNA technology coupled with plant tissue culture has helped develop novel options for the economical management of various kinds of biotic stresses including insect pests. These technologies would be of immense value in reducing the losses caused by biotic stresses, including insect pests.

Transgenic plants display considerable potential to benefit both developed and developing countries. Transgenic plants expressing insecticidal $B t$ proteins alone or in conjunction with proteins providing tolerance to herbicide are revolutionizing agriculture (Shelton et al., 2002). The use of such crops with input traits for pest management, primarily insects and herbicide resistance, has risen dramatically since their first introduction in the mid 1990s.

India, the largest cotton growing country in the world has increased productivity by up to $50 \%$ while reducing the insecticide sprays by half, with environmental and health implications, besides increased income to cultivators after introduction of $B t$ cotton in
2002. Success achieved in cotton has served as an excellent model to emulate in many other crops such as rice, wheat, pulses and oilseeds that have the potential to make agriculture a viable profession for the peasants of India.

\section{Transformation studies}

Plant transformation is now a core research tool in plant biology and a practical tool for transgenic plant development. There are many verified methods for stable introduction of novel genes into the nuclear genomes of diverse plant species. The capacity to introduce and express diverse foreign genes in plants, first described for tobacco in 1984 (DeBlock et al., 1984; Horsch et al., 1984; Paszkowski, 1984) has been extended to many plant species in at least 35 families.

Gene transfer successes include most major economic crops, vegetables and medicinal plants. As a result, gene transfer and regeneration of transgenic plants are no longer the factors limiting the development and application of practical transformation systems for many plant species. The techniques have continued to evolve to over come a great variety of barriers experienced in the early phases of the development in the field of plant transformation.

\section{Transformation methods}

Gene delivery systems involve the use of several techniques for transfer of isolated genetic materials into a viable host cell. At present, there are two classes of delivery systems (Table 1): (a) Non-biological systems (which include chemical and physical methods) and (b) Biological systems. The desire for higher transformation efficiency has stimulated work on not only improving various existing methods but also in inventing novel methods. 


\section{Biological requirements for transformation}

The essential requirements in a gene transfer system for production of transgenic plants are:

Availability of a target tissue including cells competent for plant regeneration.

A method to introduce DNA into those regenerable cells and

A procedure to select and regenerate transformed plants at a satisfactory frequency.

\section{Practical requirements for transformation}

Beyond the biological requirements to achieve transformation and the technical requirements for verification of reproducible transformation, desired characteristics to be considered in evaluating alternative techniques or developing new ones for cultivar improvement include:

(1) High efficiency, economy, and reproducibility, to readily produce many independent transformants for testing.

(2) Safety to operators, avoiding procedures, or substances requiring cumbersome precautions to avoid a high hazard to operators (e.g. potential carcinogenicity of Silicone carbide whiskers).

(3) Technical simplicity, involving a minimum of demanding or inherently variable manipulations, such as protoplast production and regeneration.

(4) Minimum time in tissue culture, to reduce associated costs and avoid undesirable somaclonal variation.

(5) Stable, uniform (nonchimeric) transformants for vegetatively propagated species, or fertile germline transformants for sexually propagated species.
(6) Simple integration patterns and low copy number of introduced genes, to minimize the probability of undesired gene disruption at insertion sites, or multicopy associated transgene silencing.

(7) Stable expression of introduced genes in the pattern expected from the chosen gene control sequences (DeBlock, 1993).

When tested against the above criteria, most published techniques for gene transfer into plant cells must be dismissed as either disproven or impractical for use in routine production of transgenic plants. As a result, in many laboratories, virtually all the transformation work relies on Particle bombardment with DNA coated microprojectiles or Agrobacterium mediated transformation for gene transfer to produce transgenic plants in a range of plant species (Birch, 1997).

\section{Non-biological based transformation}

\section{Particle bombardment/Biolistics}

Particle bombardment was first described as a method for the production of transgenic plants in 1987 (Sanford et al., 1987) as an alternative to protoplast transformation and especially for transformation of more recalcitrant cereals. Unique advantages of this methodology compared to alternative propulsion technologies are discussed elsewhere in terms of range of species and genotypes that have been engineered and the high transformation frequencies for major agronomic crops (McCabe and Christou, 1993).

In plant research, the major applications of biolistics include transient gene expression studies, production of transgenic plants and inoculation of plants with viral pathogens (Southgate et al., 1995; Sanford, 2000; Taylor and Fauquet, 2002). 
Gene constructs for biolistics can be in the form of circular or linear plasmids or a linear expression cassette. Embryogenic cell cultures are likely the best explants to use for biolistic transformation because they can be spread out as uniform targets of cells and have high recovery capacity (Kikkert et al., 2004). Rice transformation has also been successfully achieved via the bombardment of embryogenic calli (Li et al., 1993; Sivamani et al., 1996; Cao et al., 1992; Zhang et al., 1996), in which transformation efficiency has been raised to 50\% (Li et al., 1993). Particle bombardment has emerged as a reproducible method for wheat transformation (DeBlock et al., 1997; Bliffeld et al., 1999) and the first stable transformation in a commercially important conifer species (Picea glauca) was achieved via embryogenic callus tissue as explant (Ellis et al., 1993).

However, particle bombardment has some disadvantages. The transformation efficiency might be lower than with Agrobacterium mediated transformation and it is more costly, as well. Intracellular targets are random and DNA is not protected from damage. As a result, many researchers have avoided particle bombardment method because of the high frequency of complex integration patterns and multiple copy insertions that could cause gene silencing and variation of transgene expression (Dai et al., 2001; Darbani et al., 2008).

\section{Biological gene transfer}

\section{Agrobacterium mediated transformation}

The natural ability of the soil bacteria, Agrobacterium tumefaciens and Agrobacterium rhizogenus, to transform host plants has been exploited in the development of transgenic plants. In 1970s the prospect of using A. tumefaciens for the rational gene transfer of exogenous DNA into crops was revolutionary. Genetic transformation of plants was viewed as a prospect. In retrospect, Agrobacterium was the logical and natural transformation candidate to consider since it naturally transfers DNA (T-DNA) located on the tumor inducing ( $\mathrm{Ti}$ ) plasmid into the nucleus of plant cells and stably incorporates the DNA into the plant genome (Chilton et al., 1977). Now forty five years later, this method has been the most widely used and powerful technique for the production of transgenic plants. However, there still remain many challenges for genotype independent transformation of many economically important crop species, as well as forest species (Stanton, 2003; De la Riva et al., 1998).

Despite the development of other nonbiological methods of plant transformation (Shillioto et al., 1985; Uchimiya et al., 1986; Sanford, 1988; Arenchibia et al., 1992, 1995), Agrobacterium mediated transformation remains popular and is among the most effective. This is especially true among most dicotyledonous plants, where Agrobacterium is naturally infectious. Agrobacterium mediated gene transfer into monocotyledonous plants was thought to be not possible. However, reproducible and efficient methodologies have been established for rice (Hiei et al., 1994), banana (May et al., 1995, corn (Ishida et al., 1996), wheat (Cheng et al., 1997), sugarcane (Arencibia et al., 1998), forage grasses such as Italian ryegrass (Lolium multiflorum) and tall fescue (Festuca arundinacea) (Bettany et al., 2003). Among the commercially important conifers, hybrid larch was the first to be stably transformed via co-cultivation of embryogenic tissue with $A$. tumefaciens (Levee et al., 1997). Subsequently, this method was successfully applied to several species of spruce (Klimaszewska et al., 2001; Charity et al., 2005; Grant et al., 2004). 
Methods relative to transformation targets can be classified into two categories: (a) those requiring tissue culture and (b) in planta methods.

In tissue culture systems for plant transformation, the most important requirement is a large number of regenerable cells that are accessible to the gene transfer treatment and that will retain the capacity for regeneration for the duration of the necessary target preparation, cell proliferation and selection treatments. A high multiplication ratio from a micropropagation system does not necessarily indicate a large number of regenerable cells accessible to gene transfer (Livingstone and Birch, 1995). Some time gene transfer into potentially regenerable cells may not allow recovery of transgenic plants if the capacity for efficient regeneration is short lived (Ross et al., 1995). Further, tissue culture based methods can lead to unwanted somaclonal variations such as alterations in cytosine methylation, induction of point mutations and various chromosomal aberrations (Phillips et al., 1994; Singh, 2003; Clough, 2004). On the other hand, realization of whole plant transformants has been a problem in a large number of crop species as these plants have proven to be highly recalcitrant in vitro. As a result, other strategies are being evolved wherein the tissue culture component is obviated in the procedure and these are known as in planta methods.

Plant genetic transformation is of particular benefit to molecular genetic studies, crop improvement and production of pharmaceutical materials. Agrobacteriumbased methods are usually superior for many species including dicots and monocots. The others are typically not done on a routine basis (Table 2). Biolistics is by far the most widely used direct transformation procedure both experimentally in research and commercially.
So why have all these other methods emerged in the past 20-30 years, if we already have efficient transformation techniques in Agrobacterium and biolistics? There are two reasons. First of all, there is hope that a more efficient and less expensive method would be developed. The second and most important reason is the biolistics and Agrobacterium are patented.

\section{In planta transformation}

Although successful plant regeneration methods have been developed, the technology has not provided regeneration in several other crops for use in transformation protocols which is a serious limitation to the exploitation of gene transfer technology to its full potential. In the light of this major constraint, it becomes necessary to evolve transformation strategies that do not depend on tissue culture regeneration or those that substantially eliminate the intervening tissue culture steps. In planta transformation methods provide such an opportunity. Methods that involve delivery of transgenes in the form of naked DNA directly into the intact plants are called as in planta transformation methods. These methods exclude tissue culture steps, rely on simple protocols and required short time in order to obtain entire transformed individuals.

In many cases in planta methods have targeted meristems or other tissues with the assumption that at fertilization, the egg cell accepts the donation of an entire genome from the sperm cell that will ultimately give rise to zygotes (Chee and Slighton, 1995; Birch, 1997) and therefore is the right stage to integrate transgenes. For non-tissue culture based approaches of in planta transformation, Agrobacterium co-cultivation or microprojectile bombardment have been directed to transform cells in or around the apical meristems (Chee and Slighton, 1995; 
Birch, 1997). Injection of naked DNA into ovaries has also been reported to produce transformed progeny (Zhou et al., 1983).

Arabidopsis thaliana was the first plant that saw successful in planta transformation. Early stages of success in Arabidopsis transformation came from the work of Feldmann and Marks (1987). Transformation rates greatly improved when Bechtold et al. (1993) inoculated plants that were at the flowering stage. At present, there are very few species that can be routinely transformed in the absence of a tissue culture based regeneration system. Arabidopsis can be transformed by several in planta methods including vacuum infiltration (Clough and
Bent, 1998), transformation of germinating seeds (Feldmann and Marks, 1987) and floral dipping (Clough and Bent, 1998). Other plants that were successfully subjected by vacuum infiltration include rapeseed, Brassica campestris and radish, Raphanus sativus (Ian and Hong, 2001; Desfeux et al., 2000). The labor intensive vacuum infiltration process was eliminated in favor of simple dipping of developing floral tissues (Clough and Bent, 1998). Also, the results indicate that the floral spray method of Agrobacterium can achieve high rates of in planta transformation comparable to the vacuum infiltration and floral dip methods (Chung et al., 2000).

Table.1 DNA delivery methods available to produce plant transformants

\section{Plant transformation}

Non-biological based transformation (Direct method)
Biological gene transfer

(Indirect method)
A) DNA transfer in protoplasts

1) Chemically stimulated DNA uptake by protoplast

2) Electroporation

3) Lipofection

4) Microinjection

5) Sonication

B) DNA transfer in plant tissues

1) Particle bombardment / Biolistics

2) Silicon carbide fiber mediated gene transfer

3) 3) Laser microbeam (UV) induced genetransfer

\section{1) Agrobacterium mediated}

transformation

Primarily two methods

a) Co-cultivation with the explants tissue

b) In planta transformation

2) Transformation mediated by viral

(Birch et al., 1997) 
Table.2 Summary of gene delivery methods and their features

\begin{tabular}{|c|c|c|c|c|c|}
\hline $\begin{array}{l}\text { Gene delivery } \\
\text { method }\end{array}$ & $\begin{array}{c}\text { Transformation } \\
\text { efficiency }\end{array}$ & $\begin{array}{c}\text { Range of } \\
\text { transformable plant } \\
\text { species }\end{array}$ & $\begin{array}{c}\text { Tissue } \\
\text { culture phase }\end{array}$ & $\begin{array}{l}\text { Type of } \\
\text { explant }\end{array}$ & Remarks \\
\hline Electroporation & Low to high & Unrestricted & $\begin{array}{l}\text { With and } \\
\text { without tissue } \\
\text { culture phase }\end{array}$ & $\begin{array}{l}\text { Protoplasts, } \\
\text { meristems or } \\
\text { pollen grains }\end{array}$ & $\begin{array}{l}\text { Fast, simple and inexpensive in } \\
\text { contrast with biolistics }\end{array}$ \\
\hline Lipofection & Low & $\begin{array}{l}\text { Recoverable species } \\
\text { from protoplast }\end{array}$ & $\begin{array}{l}\text { With tissue } \\
\text { culture phase }\end{array}$ & Protoplast & $\begin{array}{l}\text { High efficiency with combination of } \\
\text { PEG based method, simple and non- } \\
\text { toxic }\end{array}$ \\
\hline Microinjection & High & $\begin{array}{l}\text { Recoverable species } \\
\text { from protoplast }\end{array}$ & $\begin{array}{l}\text { With tissue } \\
\text { culture phase }\end{array}$ & Protoplast & $\begin{array}{c}\text { Very slow, precise, single cell } \\
\text { targeting possibility, requires high } \\
\text { skill, the chimeric nature of transgenic } \\
\text { plants and ability of whole } \\
\text { chromosome transformation }\end{array}$ \\
\hline $\begin{array}{c}\text { Particlebombar } \\
\text { dment }\end{array}$ & High & Unrestricted & $\begin{array}{l}\text { With and } \\
\text { without tissue } \\
\text { culture phase }\end{array}$ & $\begin{array}{l}\text { Intact tissue or } \\
\text { microspores }\end{array}$ & $\begin{array}{l}\text { Efficient for viral infection, complex } \\
\text { integration patterns, without } \\
\text { specialized vectors and backbone free } \\
\text { integration }\end{array}$ \\
\hline
\end{tabular}

(Darbani et al., 2008) 


\begin{tabular}{|l|l|l|l|l|l|}
\hline $\begin{array}{l}\text { Gene delivery } \\
\text { method }\end{array}$ & $\begin{array}{c}\text { Transformation } \\
\text { efficiency }\end{array}$ & $\begin{array}{c}\text { Range of } \\
\text { transformable plant } \\
\text { species }\end{array}$ & $\begin{array}{l}\text { Tissue culture } \\
\text { phase }\end{array}$ & Type of explant & Remarks \\
\hline $\begin{array}{l}\text { Silicon carbide } \\
\text { mediate } \\
\text { transformation }\end{array}$ & Low to high & Unrestricted & $\begin{array}{l}\text { With tissue } \\
\text { culture }\end{array}$ & $\begin{array}{l}\text { Variety of cell } \\
\text { types }\end{array}$ & Rapid, inexpensive and easy to set up \\
$\begin{array}{l}\text { Laser beam } \\
\text { mediated } \\
\text { transformation }\end{array}$ & Low & Unrestricted & $\begin{array}{l}\text { With tissue } \\
\text { culture phase }\end{array}$ & $\begin{array}{c}\text { Variety of cell } \\
\text { types }\end{array}$ & Rapid and simple \\
$\begin{array}{l}\text { Agrobacterium } \\
\text { mediated } \\
\text { method }\end{array}$ & High and stable & $\begin{array}{l}\text { Many species, } \\
\text { specially } \\
\text { dicotyledonous } \\
\text { plants }\end{array}$ & $\begin{array}{l}\text { With and } \\
\text { without tissue } \\
\text { culture } \\
\text { method }\end{array}$ & $\begin{array}{l}\text { Different intact } \\
\text { cells, tissues or } \\
\text { whole plant }\end{array}$ & $\begin{array}{l}\text { Possibility of Agroinfection, } \\
\text { combination with sonication and } \\
\text { biolistic methods and transgene size } \\
\text { up to 150 kb }\end{array}$ \\
\hline $\begin{array}{l}\text { Virus based } \\
\text { method }\end{array}$ & $\begin{array}{l}\text { High and } \\
\text { transient }\end{array}$ & $\begin{array}{l}\text { Virus host specific } \\
\text { limitation }\end{array}$ & $\begin{array}{l}\text { With tissue } \\
\text { culture }\end{array}$ & $\begin{array}{l}\text { In planta } \\
\text { inoculation }\end{array}$ & $\begin{array}{l}\text { Rapid, inducible expression and with } \\
\text { mosaic status }\end{array}$ \\
\hline
\end{tabular}


Utilizing naked DNA, cotton transformants were recovered following injection of DNA into the axil placenta about a day after selfpollination (Zhou et al., 1983). Similarly, a mixture of DNA and pollen was either applied to receptive stigmatic surfaces or DNA was injected directly into rice floral tillers, or soybean seeds were imbibed with DNA (Trick and Finer, 1997; Langridge, 1992). These procedures, intriguing as they are, are impractical at present because of their low reproducibility.

Recent studies with Agrobacterium inoculation of germinating seeds of rice has provided transformation efficiencies higher than $40 \%$ (Supartana et al., 2005), while providing 4.7 to $76 \%$ efficiency for the flower infiltration method and from 2.9 to $27.6 \%$ efficiency for the seedling infiltration method (Trieu et al., 2000).

Crop species that were successfully transformed by injuring the apical meristem of the differentiated embryo of the germinating seeds and then infecting with Agrobacterium include peanut, Arachis hypogaea L. (Rohini and Rao, 2000b \& 2001), sunflower, Helianthus annuus L. (Rao and Rohini, 1999), safflower, Carthamus tinctorius L. (Rohini and Rao, 2000a), field bean, Dolichos lablab L. (Pavani, 2006), and cotton, Gossypium sp. (Keshamma et al., 2008). Maize, Zea mays L., was transformed by treating the silks with Agrobacterium and afterwards pollinated with the pollen of the same cultivar (Chumakov et al., 2006).

The above successes have in fact provided a great leverage for easy development of transgenic pants, as the methodology is simple, cost effective, does not call for high infrastructural requirement even to handle recalcitrant crops such as groundnut. Thus the technology of gene transfer for the development of recalcitrant crops has become a practical possibility for experimenting and producing viable transformants. However, the optimization of Agrobacterium-plant interaction is crucial for efficient transformation. Many factors including type of explant are important and they must be suitable to allow the recovery of whole transgenic plants (De la Ravi et al., 1998; Opabode 2006; Cheng, et al., 1997; Jones et al., 2005; Darbani et al., 2008).

Although, biotechnological advances, have provided many technologies for gene transfer into plant cells, virtually all the transformation work rely only on particle bombardment with DNA coated microprojectiles or Agrobacterium mediated transformation for gene transfer to produce transgenic plants. The review thus overwhelmingly emphasizes the importance of this method.

\section{References}

Arencibia, A., P. Molina, C. Gutierrez, A. Fuentes, V. Greenidge, E. Menendez, G. De la Riva and Housein, G. S. 1992. Regeneration of transgenic sugarcane (Saccharum officinarum L.) plants from intact meristematic tissue transformed by electroporation. Biotechnologia Aplicada 9: 156-165.

Arencibia, A. D., E. R. Carmona, P. Tellez, M. T. Chan, S. M. Yu, L. E. Trujillo and Oramas, P. 1998. An efficient protocol for sugarcane (Saccharum sp. L.) transformation mediated by Agrobacterium tumefaciens. Transgenic Res. 7(3): 213-222.

Babaoglu, M., M. R. Davey and Power, J. B. 2000. Genetic engineering of grainlegumes: key transformation events. Agri. Biotech. Net. 2:1-12.

Bechtold, N., J. Ellis and Pelletier, G. 1993. In planta Agrobacterium mediated gene transfer by infiltration of adult 
Arabidopsis thaliana plants. $C . R$. Acad. Sci. (Paris) Life Sci. 316: $1194-$ 1199.

Bennett, J. 1994. DNA-based techniques for control of rice insects and diseases: Transformation, gene tagging and DNA fingerprinting. In: Rice pest science and management, P.S. Teng, K.L. Heong and K. Moody (eds.), International Rice Research Institute, Los Banos, Philippines, pp.147-172.

Bettany, A. J. E., S. J. Dalton, E. J. Timms, B. Manderyck, M. S. Dhanoa And Morris, P. 2003. Agrobacterium tumefaciens mediated transformation of Festuca arundinacea (Sahreb.) and Lolium multiflorum (Lam.). Plant Cell Rep. 21(5): 437-444.

Birch, R. G. 1997. Plant transformation: problems and strategies for practical application. Ann. Rev. Plant Physiol. Plant Mol. Biol. 48: 297-326.

Bliffeld, M., J. Mundy, I. Potrykus and Futterer, J. 1999. Genetic engineering of wheat for increased resistance to powdery mildew disease. Theor. Applied Genet. 98(7): 1079-1086.

Cao, J., X. Duan, D. McElroy and Wu, R. 1992. Regeneration of herbicide resistant transgenic rice plants following microprojectile mediated transformation of suspension culture cells. Plant Cell Rep. 11(11): 586-591.

Charity, J. A., L. Holland, L. Grace and Walter, C. 2005. Consistent and stable expression of the nptII, uidA and bar genes in transgenic Pinus radiate after Agrobacterium tumefaciens mediated transformation using nurse cultures. Plant Cell Rep. 23(9): 606-619.

Chee, P. P. and Slighton, J. L. 1995. Transformation of soybean (Glycine max) via Agrobacterium tumefaciens and analysis of transformed plants. In: Agrobacterium protocols: Methods Mol. Biol. 44: 101-109.
Cheng, M., J. E. Fry, S. Z. Pang, H. P. Zhou, C. M. Hironaka, D. R. Duncan, W. Conner and Wan, Y. C. 1997. Genetic transformation of wheat mediated by Agrobacterium tumefaciens. Plant Physiol. 115(3): 971-980.

Chilton, M. D., M. H. Drummond, D. J. Merio, D. Sciaky, A. L. Montoya, M. P. Gordon and Nester, E. W. 1977. Stable incorporation of plasmid DNA into higher plant cells: The molecular basis of crown gall tumorigenesis. Cell 11(2): 263-271.

Chung, M. H., M. K. Chen and Pan, S. M. 2000. Floral spray transformation can efficiently generate Arabidopsis. Transgenic Res. 9(6): 471-486.

Clough, S. J. and Bent, A. F. 1998. Floral dip: a simplified method for Agrobacterium mediated transformation of Arabidopsis thaliana. Plant J. 16(6): 735-743.

Clough, S. J. 2004. Floral Dip: Agrobacterium-mediated germ line transformation. In: Methods in molecular biology. Transgenic plants: methods and protocols, Pena, L. (Ed.). Vol. 286. Humana Press Inc: Totowa, NJ. Pp: 91-102.

Dai, S., P. Zheng, P. Marmey, S. Zhang, W. Tian, S. Chen, R. N. Beachy and Fauquet, C. 2001. Comparative analysis of transgenic rice plants obtained by Agrobacterium mediated transformation and particle bombardment. Mol. Breed. 7(1): 2533.

Darbani, B., S. Farajnia, M. Toorchi, S. Zakerbostanabad, S. Noeparvar and Stewart, C. N. Jr. 2008. DNA-delivery methods to produce transgenic plants. Biotechnology 26: 1-18.

DeBlock, M. 1993. The cell biology of plant transformation: current state, problems, prospects and the implications for plant breeding. 
Euphytica 71:1-14.

DeBlock, M., H. L. Estrella, M. van Montagu, J. Schell and Zambryski, P. 1984. Expression of foreign genes in regenerated plants and their progeny. EMBO J. 3:1681-1689.

DeBlock, M., D. Debrouwer and Moens, T. 1997. The development of a nuclear male sterility system in wheat. Expression of the barnase gene under the control of tapetum specific promoters. Theor. Applied Genet. 95(1-2): 125-131.

De la Riva, G. A., J. G. Cabrera, R. V. Padron and Pardo, C. A. 1998. Agrobacterium tumefaciens: A natural tool for plant transformation. Elect. J. Biotechnol. 1(3): 118-133.

Desfeux, C., S. J. Clough and Bent, A. F. 2000. Female reproductive tissues are the primary target of Agrobacteriummediated transformation by the Arabidopsis floral -dip method. Plant Physiol. 123(3): 895-904.

Ellis, D. D., D. E. McCabe, S. McInnis, R. Ramachandran, D. R. Russell, K. Wallace, B. J. Martinell, D. R. Roberts, K. F. Raffa and McCown, B. H. 1993. Stable transformation of Picea glauca by particle acceleration. BioTechnology 11(1): 84-89.

Feldmann, K. A. and Marks, M. D. 1987. Agrobacterium mediated transformation of germinating seeds of Arabidopsis thaliana : A non-tissue culture approach. Mol. Gen. Genet. 208: 1-9.

Gatehouse, J. A. 2008. Biotechnological prospects for engineering insectresistant plants. Plant Physiol. 146: 881-887.

Grant, J. E., P. A. Cooper and Dale, T. M. 2004. Transgenic Pinus radiata from Agrobacterium tumefaciens -mediated transformation of cotyledons. Plant Cell Rep. 22(12): 894-899.
Hiei, Y., S. Ohta, T. Komari and Kumashiro, T. 1994. Efficient transformation of rice (Oryza sativa) mediated by Agrobacterium and sequence analysis of the boundaries of the T-DNA. Plant J. 6(2): 271-282.

Horsch, R. B., R. T. Fraley, S. G. Rogers, P. R. Sanders and Lloyd, A. 1984. Inheritance of functional foreign genes in plants. Science 223:496-498.

Ian, S. C. and Hong, G. N. 2001. Transgenic radish (Raphanus sativus $\mathrm{L}$. longipinnatus Bailey) by floral-dip method plant development and surfactant are important in optimizing transformation efficiency. Transgenic Res. 10(4): 363-371.

Ishida, Y., H. Saito, S. Ohta, Y. Hiei, T. Komari and Kumashiro, T. 1996. High efficiency transformation of maize (Zea mays L.) mediated by Agrobacterium tumefaciens. Nat. Biotechnol. 4: 745-750.

Jones, H. D., A. Doherty and Wu, H. 2005. Review of methodologies and protocol for the Agrobacterium-mediated transformation of wheat. Plant Methods 1: 5.

Keshamma, E., S. Rohini, K. S. Rao, B. Madhusudhan and Udayakumar, $\mathrm{M}$. 2008. Tissue culture independent in planta transformation strategy: an Agrobacterium tumefaciens-mediated gene transfer method to overcome recalcitrance in cotton (Gossypium hirsutum L.). J. Cotton Sci. 12: 264272.

Kikkert, J. R., J. R. Vidal and Reisch, B. I. 2004. Stable transformation of plant cells by particle bombardment/ Biolistics. In: Methods in molecular biology. Transgenic plants: Methods and protocols, Pena, L. (Ed.). Vol. 286, Humana Press Inc: Totowa, NJ., pp:61-78.

Klimaszewska, K., D. Lachance, G. Pelletier, 
M. A. Lelu and Seguin, A. 2001. Regeneration of transgenic Picea glauca, P. mariana and $P$. abies after co-cultivation of embryogenic tissue with Agrobacterium tumefaciens. In Vitro Cell Dev. Biol. Plant 37(6): 748755.

Langridge, P. 1992. Transformation of cereals via Agrobacterium and the pollen pathway: a critical assessment. Plant J. 2: 631-638.

Levee, V., M. A. Lelu, L. Jouanin, D. Comu and Pilate, G. 1997. Agrobacterium tumefaciens mediated transformation of hybrid larch (Larix kaempferi L. deciduas) and transgenic plant regeneration. Plant Cell Rep. 16(10): 680-685.

Li, L., R. Qu, A. Kochko de, C. M. Fauquet and Beachy, R. N. 1993. An improved rice transformation system using the biolistic approach. Plant Cell Rep. 12(1): 50-55

Livingstone, D. M. and Birch, R. G. 1995. Plant regeneration and microprojectile-mediated gene transfer in embryonic leaflets of peanut (Arachis hypogaea L.). Aust. J. Plant Physiol. 22:585-591.

May, G. D., R. Afza, H. S. Mason, A. Wiecko, F. J. Novak and Amtzen, C. J. 1995. Generations of transgenic banana (Musa acuminata) plants via Agrobacterium mediated transformation. Biotechnology 13(5): 486-492.

McCabe, D. and Christou, P. 1993. Direct DNA transfer using electric discharge particle acceleration (ACCELL ${ }^{\mathrm{TM}}$ technology). Plant Cell Tissue Organ Culture 33: 227-236.

Opabode, J. T. 2006. Agrobacteriummediated transformation of plants: Emerging factors that influence efficiency. Biotechnol. Mol. Biol. Rev. 1(1): 12-20.
Pavani, C. 2006. Development and characterisation of transgenics over expressing cry genes in field bean against Helicoverpa armigera (Hubner). M. Sc. Thesis, University of Agricultural Sciences, Bangalore, India pp.99.

Paszkowski, J., R.D. Shillito, M. Saul, V. Mandak, T. Hohn, B. Hohn and Potrykus, I. 1984. Direct gene transfer to plants. EMBO J. 3: 2717-2722.

Phillips, R. L., S. M. Kaeppler and Olhoft, P. 1994. Genetic instability of plant tissue cultures: Breakdown of normal controls. Proc. Natl. Acad. Sci. 91(12): 5222-5226.

Rao, K. S. and Rohini, V. K. 1999. Agrobacterium-mediated

transformation of sunflower (Helianthus annus L.): A simple protocol. Ann. Bot. 83: 347-354.

Rohini, V. K. and Rao, K. S. 2000a. Embryo transformation, a practical approach for realizing transgenic plants of safflower (Carthamus tinctorius L.). Ann. Bot. 86: 1043-1049.

Rohini, V. K. and Rao, K. S. $2000 \mathrm{~b}$. Transformation of peanut (Arachis hypogaea L.): a non-tissue culture based approach for generating transgenic plants. Plant Sci. 150: 4149.

Rohini, V. K. and Rao, K. S. 2001. Transformation of peanut (Arachis hypogaea $\mathrm{L}$.) with tobacco chitinase gene: variable response of transformants to leaf spot disease. Plant Sci. 160: 889-898.

Ross, A. H., J. M. Manners and Birch, R. G. 1995. Embryogenic callus production, plant regeneration and transient gene expression following particle bombardment, in the pasture grass Cenchrus ciliarus (Gramineae). Aust. J. Bot. 43:193-199.

Sanford, J. C., T. M. Klein, E. D. Wolf and 
Allen, N. 1987. Delivery of substances into cells and tissues using a particle bombardment process. Particulate Sci. Technol. 5(1): 27-37.

Sanford, J. C. 2000. The development of the biolistic process. In vitro Cell Dev. Biol. Plant 36(5): 303-308.

Shelton, A. M., J. Z. Zhao and Roush, R. T. 2002. Economic, ecological, food safety and Social consequences of the deployment of $B t$ transgenic plants. Annu. Rev. Entomol. 47: 845-881.

Singh, R. J. 2003. Chromosomal aberrations in cell and tissue culture. In: Plant cytogenetics, Singh, R. J. (Ed.). CRC Press: Boca Raton, Fl., pp: 307-326.

Sivamani, E., P. Shen, N. Opalka, R. N. Beachy and Fauquet, C. M. 1996. Selection of large quantities of embryogenic subcultured calli from indica rice seeds for production of fertile transgenic plants using the biolistic method. Plant Cell Rep. 15(5): 322-327.

Southgate, E. M., M. R. Davey, J. B. Power and Marchant, R. 1995. Factors affecting the genetic engineering of plants by Microprojectile bombardment. Biotechnol. Adv. 13(4): 631-651.

Stanton, B. G. 2003. Agrobacterium mediated plant transformation: The biology behind the gene jockeying tool. Microbiol. Mol. Biol. Rev. 67(1): 1637.

Supartana, P., T. Shimizu, H. Shioiri, M.
Nogawa, M. Nozue and Kojima, M. 2005. Development of simple and efficient in planta transformation method for rice (Oryza sativa L.) using Agrobacterium tumefaciens. J. Biosci. Bioengg. 100 (4): 391-397.

Taylor, N. J. and Fauquet, C. M. 2002. Microparticle bombardment as a tool in plant science and agricultural biotechnology. DNA Cell Biol. 21(12): 963-977.

Trick, H. N. and Finer, J. J. 1997. SAAT: Sonication-assisted Agrobacteriummediated transformation. Transgenic Res. 6(5): 329-336.

Trieu, A. T., S. H. Burleigh, I. V. Kardailsky, I. E. M. Mendoza, W. K. Versaw, L. A. Blaylock, H. Shin, T. J. Chiou, H. Katagi, G. R. Dewbre, D. Weigel and Harrison, M. J. 2000. Transformation of Medicago truncatula via infiltration of seedlings of flowering plants with Agrobacterium. Plant J. 22(6): 531541.

Zhang, S., L. Chen, R. Qu, P. Marmey, R. N. Beachy and Fauquet, C. M. 1996. Regeneration of fertile transgenic indica (group 1) rice plants following microprojectile transformation of embryogenic suspension culture cell. Plant Cell Rep. 15(7): 465-469.

Zhou, G. Y., J. Weng, Y. Zeng, J. Huang, S. Qian and Liu, G. 1983. Introduction of exogenous DNA into cotton embryos. Meth. Enzymol. 101: 433-481.

\section{How to cite this article:}

Keshavareddy, G., A.R.V. Kumar and Vemanna S. Ramu. 2018. Methods of Plant Transformation- A Review Int.J.Curr.Microbiol.App.Sci. 7(07): 2656-2668. doi: https://doi.org/10.20546/ijcmas.2018.707.312 